OPEN ACCESS

Edited by:

Jun-Lin Yi,

Chinese Academy of Medical

Sciences and Peking Union Medical

College, China

Reviewed by:

Kathryn Huber,

Tufts University School of Medicine,

United States

Ying Sun,

Sun Yat-sen University Cancer Center

(SYSUCC), China

*Correspondence:

Xiaoshen Wang

ruijin702@163.com

${ }^{\text {t}}$ These authors have contributed equally to this work

Specialty section: This article was submitted to

Radiation Oncology,

a section of the journal

Frontiers in Oncology

Received: 10 August 2020 Accepted: 03 December 2020

Published: 21 January 2021

Citation:

Zhou X, Liu P and Wang X (2021)

Temporal Lobe Necrosis

Following Radiotherapy in

Nasopharyngeal Carcinoma: New Insight Into the Management.

Front. Oncol. 10:593487.

doi: 10.3389/fonc.2020.593487

\section{Temporal Lobe Necrosis Following Radiotherapy in Nasopharyngeal Carcinoma: New Insight Into the Management}

\author{
Xin Zhou ${ }^{1,2 t}$, Peiyao Liu ${ }^{1,2 t}$ and Xiaoshen Wang ${ }^{3 *}$ \\ ${ }^{1}$ Department of Radiation Oncology, Fudan University Shanghai Cancer Center, Shanghai, China, ${ }^{2}$ Department of Oncology, \\ Shanghai Medical College, Fudan University, Shanghai, China, ${ }^{3}$ Department of Radiation Oncology, Eye and ENT Hospital, \\ Fudan University, Shanghai, China
}

Cerebral radiation necrosis $(\mathrm{CRN})$ is one of the most prominent sequelae following radiation therapy for nasopharyngeal carcinoma (NPC), which might have devastating effects on patients' quality of life (QOL). Advances in histopathology and neuro-radiology have shed light on the management of CRN more comprehensively, yet effective therapeutic interventions are still lacking. CRN was once regarded as progressive and irreversible, however, in the past 20 years, with the application of intensity-modulated radiation therapy (IMRT), both the incidence and severity of CRN have declined. In addition, newly developed medical agents including bevacizumab-a humanized monoclonal antibody against vascular endothelial growth factor (VEGF), nerve growth factor (NGF), monosialotetrahexosylganglioside (GM1), etc., have shown great potency in successfully reversing radiation-induced $\mathrm{CRN}$. As temporal lobes are most frequently compromised in NPC patients, this review will summarize the state-of-the-art progress regarding the incidence, pathophysiology, prevention, treatment, and prognosis of temporal lobe necrosis (TLN) after IMRT in NPC.

\footnotetext{
Keywords: cerebral radiation necrosis, pathophysiology, bevacizumab, monosialotetrahexosylganglioside, nerve growth factor
}

\section{INTRODUCTION}

Nasopharyngeal carcinoma (NPC) constitutes the largest proportion of head and neck malignancies in China and Southeast-Asia, and radiation therapy (RT) is the mainstay treatment for non-metastatic cases. In the past decade, advances in intensity-modulated radiation therapy (IMRT) have allowed for improved spatial dose distribution, hence better preserving organs at risk (OARs). However, due to the anatomical proximity between nasopharynx and cerebrum, cerebral radiation necrosis (CRN) remains conspicuous as a late complication following IMRT. Particularly, for those with skull-base or intracranial invasion, overlap with radiation target volumes tends to generate dosimetric "hot spots" in temporal lobes (TLs) even with IMRT (1), making temporal lobe necrosis (TLN) a relatively common form of CRN in NPC. As is frequently accompanied with symptomatic abnormalities such as lethargy, dizziness, debilitation, emotional disorders, cognitive dysfunction, and even epileptic attacks, TLN may 
significantly impair survivors' quality of life (QOL) (2). Accumulating evidence have suggested the etiology and pathogenesis of CRN, nevertheless, many questions remain unanswered regarding its management. This review, with emphasis on therapeutic perspective, will focus on CRN, especially TLN after radiotherapy for NPC.

\section{INCIDENCE AND RISK FACTORS OF TEMPORAL LOBE NECROSIS}

TLN is a joint effect of genetic, clinical, and RT-related factors (Table 1) (3-10). Radiation techniques and RT parameters constitute the most critical part of RT-related factors. RT parameters, including dose fractionation, total radiation dose, irradiated volume, etc., were thought to most profoundly affect the development of TLN. Generally, increased total RT dose or larger dose per fraction is associated with escalating risk of TLN and shortened latency (11). The evolution in RT technique have also led to a fundamental change in CRN incidence. Back in the era of two-dimensional conventional radiotherapy (2D-CRT), with different fractionation strategy, the incidence of TLN varied from 1.6 to $22 \%$ at an interval of 9 months to 16 years after treatment $(12,13)$. Lee et al. reported that a total dose of $64 \mathrm{~Gy}$ in 32 fractions would lead to $5 \%$ necrotic rate in 10 years (9). However, with IMRT widely used in NPC, the rate of TLN tended to decline in long-term survivors. Zhou et al. retrospectively reviewed 1,276 NPC patients and found that IMRT yielded a significantly decreased 5-year actuarial incidence of TLN (16.0 vs. 34.9\%, P < 0.001) (4). Another study, through prospectively randomization, also found that NPC patients receiving IMRT had lower rate of TLN (13.1 vs.
21\%) (10). Meanwhile, in comparison to the commonly seen bilateral TLN lesions in 2D-CRT era, IMRT-induced TLN mostly occurred ipsilaterally with reduced size (14). These improvements, to a large extent, might be attributed to the dosimetric advantage of IMRT in sparing temporal lobes by reducing regions with high-dose irradiation (15).

Non-RT factors, such as genetic susceptibility, chemotherapy, and targeted therapy, might exacerbate the occurrence of TLN. According to Wang et al., centrosome protein CEP128 links to the maintenance of cell radioresistance, downregulation of CEP128 by genetic variants could remarkably add to the radiation damage of glial cells, and further increase the risk of CRN (3). Ruben et al. reported that post-RT chemotherapy enhanced the hazard of CRN by approximately fivefold in patients with glioma (16). In NPC, chemotherapy was also reported to be an independent risk factor that promoted the 5year incidence of TLN from 1.9\%to 10.1\% (5). The impact of targeted agents on TLN is yet uncertain, but some studies have suggested that cetuximab, a monoclonal antibody to epidermal growth factor receptor (EGFR), might confer relatively high risk of TLN when used concurrently with RT in both treatment-naïve and recurrent NPC patients $(6,7)$. Future work is warranted to specifically illustrate the role of anti-EGFR agents in TLN development as well as the potential biological mechanisms.

\section{PATHOPHYSIOLOGY OF RADIATION INDUCED NECROSIS TO THE BRAIN}

RT induced brain injury includes early-phase changes such as acute edema or subacute demyelination, and late changes featured by delayed CRN. While acute edema could be

TABLE 1 | Risk factors of radiation-induced temporal lobe injury in nasopharyngeal carcinoma.

\begin{tabular}{|c|c|c|c|c|c|}
\hline Risk factors & Authors & Study type & Enrolled patients & RT technique & Results \\
\hline $\begin{array}{l}\text { Genetic } \\
\text { susceptibility }\end{array}$ & Wang et al. (3) & $\begin{array}{l}\text { Prospective, } \\
\text { observational }\end{array}$ & $\begin{array}{l}\text { Discovery stage: 1,082; Validation } \\
\text { stage I: 1,119; Validation stage II: } \\
741\end{array}$ & 2D-RT; IMRT & $\begin{array}{l}\text { Minor alleles at rs162171 or rs17111237 are related to } \\
\text { higher risk of TLI (per allele HR, } 1.46 \text { and 1.45). }\end{array}$ \\
\hline Tumor stage & Zhou et al. (4) & Retrospective & 1,276, firstly diagnosed NPC & 2D-RT; IMRT & $\begin{array}{l}\text { T classification is an independent predictor of TLI (T3-4 vs. } \\
\text { T1-2 HR, 2.777). }\end{array}$ \\
\hline Chemotherapy & Zeng et al. (5) & Retrospective & 789, firstly diagnosed NPC & IMRT & $\begin{array}{l}\text { Chemoradiation vs. RT: } 5 \text {-year actuarial incidence of TLN, } \\
10.1 \text { vs. } 1.9 \%(\mathrm{HR}, 2.58, \mathrm{P}=0.030) \text {. }\end{array}$ \\
\hline \multirow[t]{2}{*}{$\begin{array}{l}\text { Targeted } \\
\text { therapy }\end{array}$} & Niu et al. (6) & Retrospective & 33, firstly diagnosed NPC & IMRT & $\begin{array}{l}\text { Concurrent cetuximab plus IMRT with/out chemotherapy: } \\
\text { unexpectedly high TLN rate, } 21.2 \% \text {. }\end{array}$ \\
\hline & $\mathrm{Ng}$ et al. (7) & $\begin{array}{l}\text { Prospective, } \\
\text { single-arm, } \\
\text { phase II }\end{array}$ & 33, recurrent T3-4 NPC & IMRT & $\begin{array}{l}\text { Concurrent bio-chemoradiation with cetuximab: high TLN } \\
\text { rate, } 30.8 \% \text {. }\end{array}$ \\
\hline \multirow[t]{2}{*}{$\begin{array}{l}\text { Fractional } \\
\text { dose }\end{array}$} & Teo et al. (8) & Retrospective & 159, firstly diagnosed NPC & 2D-RT & $\begin{array}{l}\text { Late course HART (1.6 Gy, twice daily) vs. conventional } \\
\text { fractionation ( } 2.5 \text { Gy daily): TLN rate, } 40.2 \text { vs. } 19.5 \% \text {. }\end{array}$ \\
\hline & Lee et al. (9) & Retrospective & 1,008, firstly diagnosed NPC & 2D-RT & $\begin{array}{l}\text { Hypofractionation ( } 4.2 \text { Gy daily) vs. conventional } \\
\text { fractionation ( } 2.5 \text { Gy daily): 10-year actuarial incidence of } \\
\text { TLN, } 18.6 \text { vs. } 4.6 \% \text {. }\end{array}$ \\
\hline RT technique & Peng et al. (10) & $\begin{array}{l}\text { Prospective, } \\
\text { randomized, } \\
\text { phase III }\end{array}$ & 616, firstly diagnosed NPC & 2D-RT; IMRT & 2D-CRT vs. IMRT: TLN rate, 21.0 vs. $13.1 \%$. \\
\hline
\end{tabular}

NPC, nasopharyngeal carcinoma; 2D-RT, two-dimensional radiotherapy; HART, hyperfractionated accelerated radiotherapy; IMRT, intensity-modulated radiotherapy; TLI, temporal lobe injury; TLN, temporal lobe necrosis; HR, hazard ratio. 
reversed with timely intervention, CRN usually presents with an unpredictable pattern of evolution, bringing more difficulty to the recognition of its pathogenesis and management. Up to now, the mechanisms of CRN development have not been completely understood. The typical pathological presentation of CRN was first described by Lowenberg-Scharenberg et al. as amyloid degeneration in 1950 (17). Subsequent investigations found that CRN was histologically featured by coagulation necrosis in the white matter, presenting fibrinoid necrosis and hyalinization of vessel walls, telangiectasis, dystrophic calcification as well as surrounding inflammation and gliosis (18). Immunohistochemistry further showed expression of hypoxia-inducible factor-1a (HIF-1 $\alpha$ ), vascular endothelial growth factor (VEGF) and inflammatory cytokines like Interleukin- 6 and tumor necrosis factor (TNF)- $\alpha$ in glial cells near necrotic area (19). Based on published literatures, RT-induced cerebral tissue injury is a highly complex process that involves multiple tissue elements (20-22). Three models have been postulated to eventually contribute to the occurrence of CRN: (a) vascular endothelial injury: radiation injury to endothelial cells and following apoptosis provokes massive release of oxygen free radicals, hence inducing upregulation of HIF-1 $\alpha$ and VEGF, causing blood-brain-barrier (BBB) disruption, vasogenic edema, platelet and fibrin thrombi formation, vessel occlusion, and ischemic changes. (b) injury to glial/progenitor cells: radiation can directly damage astrocytes, oligodendrocytes, and their progenitors, correspondingly causing hypocellular architectural changes such as BBB breakdown with worsened edema and hypoxia, astrogliosis, and demyelination. The production of VEGF and delayed release of TNF- $\alpha$ by microglia and astrocytes in perinecrotic zone further aggravates this process, eventually forming a vicious cycle. (c) immuno-inflammation induced injury: under radiation stress, lymphocytes and macrophages infiltrate in perivascular and parenchymal spaces, actively secreting inflammatory cytokines; microglia cells are also stimulated and contribute to the inflammatory response, exacerbating BBB permeability defect and hypoxia-induced necrosis (18-22). In general, vascular injuryinduced white matter edema occurs as an acute toxicity, followed by glial cell-related subacute demyelination, and eventually evolutes into a delayed phase of brain necrosis (23-25).

\section{PREVENTION OF CEREBRAL RADIATION NECROSIS}

Despite the multiple pharmacological efforts to treat CRN, the most pragmatic and cost-effective approach to manage remains prevention. As more dose-volume-histogram (DVH) data being published, consensus has been established that CRN is actually a function of both irradiation dose and volume. For temporal lobes, currently the most widely accepted dose constraint is the recommendation from Radiation Therapy Oncology Group (RTOG) 0225, which confined the maximum dose (Dmax) to lower than $60 \mathrm{~Gy}$ and $1 \%$ of the temporal lobe volume not exceeding 65 Gy (26). This constraint, however, might be too stringent sometimes, especially in those with locally advanced NPC that locate adjacently or even overlapped with temporal lobes. According to Su et al., no temporal lobe with Dmax $<64$ Gy had necrosis, but the incidence increases by $2.6 \%$ per Gy increment of Dmax once exceeding 64 Gy. They further recommended Dmax $<68$ Gy as a safe constraint for IMRT plans (27). Zeng et al. reported an escalating 5 -year TLN rate from $0.8 \%$ in TLs with Dmax $<65.77$ Gy to $27.1 \%$ in those with greater dose (5). Another analysis by Zeng et al. plotted the dose-response curves and estimated the tolerance dose (TD) for the $5 \%$ probability of TLI at 62.83 Gy equivalents (28). Kong et al. estimated TD5/5 of TLN was Dmax at $69.0 \pm 1.6 \mathrm{~Gy}$ and D1cc (maximum dose delivered to a volume of $1 \mathrm{ml}$ ) at $62.8 \pm 2.2 \mathrm{~Gy}(29)$. Wang et al. determined through LASSO (least absolute shrinkage and selection operator) regressions that $\mathrm{D} 0.5 \mathrm{cc}$ and $\mathrm{D} 10$ were reliable dosimetric predictors of TLN (30). These studies suggested that the maximum dose to TLs might be safely loosened under specific circumstances. Therefore, the 2019 international guideline of RT planning for NPC recommended a stepwise dose constraint for temporal lobes: D0.03cc $\leq 65$ Gy for early stage and $\leq 70$ Gy for advanced stage. In the difficulty of balancing TL protection and tumor control, even D0.03cc $\leq 72$ Gy could be accepted (31). In another aspect, new concerns were raised regarding the role of volumetric factors in TLN development. Su et al. found that $\mathrm{aV}_{40}$ (absolute volume receiving dose over $40 \mathrm{~Gy}$ ) and $\mathrm{rV}_{40}$ (the percentage of $\mathrm{V} 40$ in total TL volume) in TLs as independent risk factors for TLN, and further proposed new dose constraints of $\mathrm{rV}_{40}<10 \%$ or $\mathrm{aV}_{40}<5$ cc to TLs (32). Zhou et al. further investigated the relationship between volumetric factors and the extent of TLN, and drew a conclusion that $\mathrm{V}_{45}>15.1 \mathrm{cc}$ tended to induce larger lesion when TLN happened (33). Therefore, inverse IMRT plans should maximally avoid not only focal "hot spot" dose, but also moderate dose delivered to a large area in TLs. Details of dose constraint recommendation are listed in Table 2 (1, 27-30, 32-37).

Another plausible way to reduce the probability of CRN is based on stem cells. It has been previously demonstrated that radiation would weaken the reproductive capacity of O-2A progenitor cells (38-40) and eventually lead to CNS demyelination (41, 42). Accordingly, retransplantation of purified O-2A cells could remyelinate these lesions (43). Totipotent embryonic stem (ES) cells were also introduced as an unlimited donor for transplantation, given their self-renewing and multiple differentiation capacity. Brustle et al. found that transplantation of ES cells-derived precursors for oligodendrocytes and astrocytes could efficiently myelinated axons in CNS in a rat model with human myelin disease (44). Ijichi et al., through another in vivo study, suggested that the implantation of platelet derived growth factor (PDGF)-expressing cells increased O$2 \mathrm{~A}$ progenitors in adult rat spinal cord without compromising their proliferation or differentiation potential (45). However, none of these strategies have ever been tested in patients with radiation necrosis, and future investigations are warranted.

\section{CONVENTIONAL MANAGEMENT AND OUTCOMES}

It was once acknowledged that CRN represents a frequently irreversible and even progressive complication of radiotherapy (46), 
TABLE 2 | Dose constraints to prevent TLN in IMRT planning for nasopharyngeal carcinoma.

\begin{tabular}{|c|c|c|c|c|c|}
\hline Authors & Study type & Study objects & Variables & Results & $\begin{array}{l}\text { Proposed dose } \\
\text { constraints }\end{array}$ \\
\hline Sun et al. (1) & $\begin{array}{l}\text { Case- } \\
\text { controlled }\end{array}$ & $\begin{array}{l}20 \text { patients, } 20 \text { pairs of necrotic } \\
\text { and normal TLs }\end{array}$ & $\mathrm{D} 0.5 \mathrm{cc}$ & AUC for D0.5cc in predicting TLN = 0.843. & D0.5cc<69 Gy \\
\hline Su et al. (27) & $\begin{array}{l}\text { Cohort, } \\
\text { retrospective }\end{array}$ & $\begin{array}{l}251 \text { patients, } 43 \text { necrotic and } \\
431 \text { normal TLs }\end{array}$ & $\begin{array}{l}\text { Dmax, } \\
\text { D1cc }\end{array}$ & $\begin{array}{l}\text { TLN incidence augmented by } 2.6 \text { and } 2.5 \% \text { per Gy for Dmax } \\
>64 \text { Gy and D1cc }>52 \text { Gy, respectively. }\end{array}$ & $\begin{array}{l}\text { Dmax<68 Gy; } \\
\text { D1cc<58 Gy }\end{array}$ \\
\hline Zeng et al. (5) & $\begin{array}{l}\text { Cohort, } \\
\text { retrospective }\end{array}$ & $\begin{array}{l}230 \text { patients, } 48 \text { necrotic and } \\
412 \text { normal TLs }\end{array}$ & Dmax & $\begin{array}{l}\text { 5-year TLN incidence for TLN: } \\
\text { Dmax } \geq 65.77 \text { Gy, } 0.8 \% \\
\text { Dmax }<65.77 \text { Gy, } 27.1 \%\end{array}$ & Dmax<65.77 Gy \\
\hline Zeng et al. (28) & $\begin{array}{l}\text { Cohort, } \\
\text { retrospective }\end{array}$ & $\begin{array}{l}278 \text { patients, } 35 \text { necrotic and } \\
517 \text { normal TLs }\end{array}$ & D1cc & $\begin{array}{l}\text { TD5/5 for D1cc = } 62.8 \text { Gy; } \\
\text { TD50/5 for D1Cc = } 77.6 \text { Gy. }\end{array}$ & D1cc $<62.8$ Gy \\
\hline Kong et al. (29) & $\begin{array}{l}\text { Cohort, } \\
\text { retrospective }\end{array}$ & $\begin{array}{l}132 \text { patients, } 42 \text { necrotic and } \\
222 \text { normal TLs }\end{array}$ & $\begin{array}{l}\text { Dmax, } \\
\text { D1cc }\end{array}$ & $\begin{array}{l}\text { TD5/5 for } \mathrm{Dmax}=69.0 \pm 1.6, \mathrm{TD} 50 / 5 \text { for } \mathrm{Dmax}=82.1 \pm 2.4 \text { Gy; } \\
\text { TD5/5 for } \mathrm{D} 1 \mathrm{cc}=62.8 \pm 2.2, \mathrm{TD} 50 / 5 \text { for } \mathrm{D} 1 \mathrm{cc}=80.9 \pm 3.4 \text { Gy. }\end{array}$ & $\begin{array}{l}\text { Dmax }<69.0 \text { Gy; } \\
\text { D1cc }<62.8 \text { Gy }\end{array}$ \\
\hline Wang et al. (30) & $\begin{array}{l}\text { Cohort, } \\
\text { retrospective }\end{array}$ & $\begin{array}{l}749 \text { patients, } 79 \text { necrotic and } \\
1419 \text { TLs }\end{array}$ & $\begin{array}{l}\text { D0.5cc, } \\
\text { D10 }\end{array}$ & LASSO prediction model with D0.5cc and D10: C-index, 0.685. & NA \\
\hline Su et al. (32) & $\begin{array}{l}\text { Cohort, } \\
\text { retrospective }\end{array}$ & $\begin{array}{l}259 \text { patients, } 47 \text { necrotic } \\
\text { and } 454 \text { normal TLs }\end{array}$ & $\begin{array}{l}\mathrm{aV} 40 \\
\mathrm{rV} 40\end{array}$ & $\begin{array}{l}5 \text {-year TLN incidence: } \\
\text { aV40<5cc or } r V 40<10 \% \text {, less than } 5 \% \text {; } \\
\text { aV } 40 \geq 10 c c \text { or } r V 40>15 \% \text {, more than } 20 \% \text {. }\end{array}$ & $\begin{array}{l}\text { rV40<10\%; } \\
\text { aV40<5 cc }\end{array}$ \\
\hline Zhou et al. (33) & $\begin{array}{l}\text { Case- } \\
\text { controlled }\end{array}$ & $\begin{array}{l}86 \text { patients, } 53 \text { necrotic and } 119 \\
\text { normal TLs }\end{array}$ & V45 & $\begin{array}{l}\text { ORs increased with Dvs and Vds; } \\
\text { V45 is predictive of TLN volume. }\end{array}$ & V45<15.1 cc \\
\hline Feng et al. (34) & $\begin{array}{l}\text { Cohort, } \\
\text { retrospective }\end{array}$ & $\begin{array}{l}436 \text { patients, } 81 \text { necrotic and } \\
780 \text { normal TLs }\end{array}$ & $\mathrm{D} 2 \mathrm{cc}$ & $\begin{array}{l}\text { TD5/5 for D2cc = } 60.3 \text { Gy; } \\
\text { TD50/5 for D2cc = } 76.9 \text { Gy. }\end{array}$ & D2cc<60.3 Gy \\
\hline Lu et al. (35) & $\begin{array}{l}\text { Cohort, } \\
\text { retrospective }\end{array}$ & $\begin{array}{l}188 \text { patients, } 94 \text { necrotic and } \\
282 \text { normal TLs }\end{array}$ & V70 & AUC for $V 70$ in predicting TLN = 0.75 & V70<1.13 cc \\
\hline Huang et al. (36) & $\begin{array}{l}\text { Case- } \\
\text { controlled }\end{array}$ & $\begin{array}{l}126 \text { T4 patients, } 83 \text { necrotic and } \\
169 \text { normal TLs }\end{array}$ & $\begin{array}{l}\text { D1cc, } \\
\text { V20 }\end{array}$ & $\begin{array}{l}\text { D1cc }>71.1 \text { Gy vs. } \leq 71.1 \text { Gy: OR for TLN, } 7.92 \\
\text { V20 > } 42.2 \text { cc vs } \leq 42.2 \text { cc: OR for TLN, 3.12. }\end{array}$ & $\begin{array}{l}\text { D1cc }<71.14 \text { Gy; } \\
\text { V20<42.2 cc }\end{array}$ \\
\hline Gou et al. (37) & $\begin{array}{l}\text { Cohort, } \\
\text { retrospective }\end{array}$ & $\begin{array}{l}166 \text { T3-4 patients, } 22 \text { necrotic } \\
\text { and } 310 \text { normal TLs }\end{array}$ & Dmax & AUC for Dmax in predicting TLN = 0.861 & Dmax $<78$ Gy \\
\hline
\end{tabular}

TLN, temporal lobe necrosis; IMRT, intensity-modulated radiotherapy; AUC, area under receiver operating characteristic curve; LASSO, least absolute shrinkage and selection operator;

$T D$, tolerance dose; TL, temporal lobe; OR, odd ratio; NA, not available.

where conventional therapeutic approaches usually showed limited effectiveness. For decades, treatment strategy for CRN tended to be less aggressive, patients with asymptomatic CRN might be recommended to "wait and see," while interventions were adopted mostly for those with typical symptoms or signs, including corticosteroids, anticoagulants, hyperbaric oxygen and surgery, etc. (Table 3) (47-54).

\section{Management With Corticosteroids}

A common practice for the treatment of CRN is using corticosteroids for necrosis-related edema. Dexamethasone usually produces prompt symptomatic relief in patients with focal RT necrosis and concomitant edema. Radiological improvement can also be found in certain cases receiving corticosteroids. However, this improvement is usually transient and steroid-dependent, leading to a rapid relapse once corticosteroids are stopped (47). Another concern was the potential risk of myriad debilitating chronic adverse effects with long-term use of corticosteroids, such as myopathy, endocrine and metabolic disorders, cardiovascular malfunctions, etc. In general, pulsed corticosteroid treatment would confer favorable response in terms of space occupying edema-related symptoms, but prolonged course and high-dose of corticosteroids should be given with special caution. Zhuo et al. reported that high-dose intravenous methylprednisolone is no superior to low-dose agent in treating $\mathrm{CRN}$, thus recommending the use of corticosteroids as $1 \mathrm{mg} / \mathrm{kg}$ /day methylprednisolone for 5 days, then $40 \mathrm{mg}$ for another 5 days, then oral prednisone for $30 \mathrm{mg} /$ day initially, followed by gradual tapering by $5 \mathrm{mg} /$ week to $10 \mathrm{mg} /$ day. The maintenance period shouldn't exceed 3 months (60).

\section{Management With Surgery}

Surgical debulking of the necrotic brain tissue can provide helpful palliative effect for patients who fail to show adequate response to conservative treatments. Case series have shown that proper surgical intervention might rapidly ameliorate life-threatening intracranial hypertension and terminate inflammatory cascade reaction in brain tissue $(53,54)$. However, ample evidence also suggested that surgical intervention is not always necessary, for instance, symptoms will partially resolve with corticosteroid therapy alone in some cases, some necrotic lesions are inaccessible to surgery, and several focal necrosis would continue to deteriorate even after surgical debulking due to progressive necrosis near the original site $(61,62)$. In addition, gross total resection of necrotic debris has been demonstrated with no significant survival benefit when compared to conservative management (16).

\section{Management With Anticoagulants}

Therapeutic anticoagulation has also been adopted to halt the progression of CRN based on a thought that CRN derives mainly from vascular damage-associated ischemia. Glantz et al. reported hopeful functional recovery in patients with CRN using heparin and warfarin anticoagulation (49). However, another case series found only modest efficacy of anticoagulation therapy on postradiation neurotoxicity (48). Since these are only small size studies, solid conclusions can barely be drawn towards anticoagulation. Moreover, when using anticoagulants for 
TABLE 3 | Comparisons of conventional and novel treatment approaches for CRN.

\begin{tabular}{|c|c|c|c|c|c|c|}
\hline \multirow[t]{2}{*}{ Treatment } & \multirow[t]{2}{*}{ Medications } & \multirow[t]{2}{*}{ Evidence } & \multicolumn{3}{|c|}{ Therapeutic effects } & \multirow[t]{2}{*}{ Adverse effects } \\
\hline & & & Edema & Necrosis & Clinical symptoms & \\
\hline \multicolumn{7}{|l|}{$\begin{array}{l}\text { Conventional } \\
\text { treatment }\end{array}$} \\
\hline $\begin{array}{l}\text { Corticosteroids } \\
(47)\end{array}$ & $\begin{array}{l}\text { Methylprednisolone, } \\
\text { prednisolone, } \\
\text { dexamethasone }\end{array}$ & Cohort & $\begin{array}{l}\text { Rapid, strong; } \\
\text { Non-durable }\end{array}$ & Irreversible & $\begin{array}{l}\text { Rapid remission of hypertension; weak } \\
\text { effect on localized symptoms }\end{array}$ & $\begin{array}{l}\text { Infection; osteoporosis; peptic } \\
\text { ulcer; central obesity; } \\
\text { hyperglucomia }\end{array}$ \\
\hline $\begin{array}{l}\text { Anticoagulants } \\
(48,49)\end{array}$ & Heparin, warfarin & $\begin{array}{l}\text { Case } \\
\text { series }\end{array}$ & Partial response & Irreversible & $\begin{array}{l}\text { Minor-mild improvement on cerebral } \\
\text { function }\end{array}$ & Bleeding \\
\hline $\begin{array}{l}\text { Hyperbaric } \\
\text { oxygen }(50-52)\end{array}$ & NA & $\begin{array}{l}\text { Case } \\
\text { series }\end{array}$ & Partial response & Irreversible & $\begin{array}{l}\text { Minor-mild improvement on cerebral } \\
\text { function }\end{array}$ & Ear barotrauma, dyspnea \\
\hline $\begin{array}{l}\text { Surgery }(53, \\
54),\end{array}$ & NA & $\begin{array}{l}\text { Case } \\
\text { series }\end{array}$ & $\begin{array}{l}\text { Instant, radical; } \\
\text { Possibly relapse }\end{array}$ & $\begin{array}{l}\text { Instant, radical; } \\
\text { Possibly relapse }\end{array}$ & $\begin{array}{l}\text { Instant remission of localized symptoms } \\
\text { such as epilepsy; restoration of } \\
\text { deteriorating cerebral function }\end{array}$ & $\begin{array}{l}\text { Infection, bleeding, permanent } \\
\text { neurological deficits, life- } \\
\text { threatening in high-risk cases }\end{array}$ \\
\hline \multicolumn{7}{|l|}{$\begin{array}{l}\text { Novel } \\
\text { treatment }\end{array}$} \\
\hline $\begin{array}{l}\text { anti-VEGF }(55 \text {, } \\
56) \text {, }\end{array}$ & Bevacizumab & $\mathrm{RCT}$ & $\begin{array}{l}\text { Rapid, strong; } \\
\text { Non-durable }\end{array}$ & Partly reversible & $\begin{array}{l}\text { Rapid remission of hypertension and } \\
\text { significant improvement on cerebral } \\
\text { function }\end{array}$ & $\begin{array}{l}\text { Bleeding, venous thrombosis, } \\
\text { hypertension, aspiration } \\
\text { pneumonia }\end{array}$ \\
\hline $\begin{array}{l}\text { Free radical } \\
\text { scavengers (57) }\end{array}$ & Edaravone & $\mathrm{RCT}$ & Partial response & $\begin{array}{l}\text { No additional } \\
\text { improvement } \\
\text { besides steroids }\end{array}$ & $\begin{array}{l}\text { Significant improvement on neurologic } \\
\text { symptoms and signs with LENT/SOMA } \\
\text { scale }\end{array}$ & $\begin{array}{l}\text { Insomnia, hyperglucomia, liver } \\
\text { dysfunction }\end{array}$ \\
\hline $\begin{array}{l}\text { Gangliosides } \\
(58)\end{array}$ & GM1 & Preclinical & NA & NA & $\begin{array}{l}\text { Neuroprotective effect on learning and } \\
\text { memory impairment in rats with } \mathrm{CRN}\end{array}$ & NA \\
\hline NGF (59) & NGF & RCT & $\begin{array}{l}\text { Rapid remission } \\
\text { (with steroids) }\end{array}$ & $\begin{array}{l}\text { High response } \\
\text { rate, reversible }\end{array}$ & $\begin{array}{l}\text { Durable remission of both hypertension } \\
\text { and localized symptoms }\end{array}$ & Pain at the injection site \\
\hline
\end{tabular}

CRN, cerebral radiation necrosis; RCT, randomized clinical trial; LENT/SOMA, late effects normal tissue/subjective objective management analytic; NGF, nerve growth factor; GM1, monosialotetrahexosylganglioside; NA, not applicable.

CRN, one should take special caution that they might potentially cause bleeding, and the pros and cons should be weighed.

\section{Alternative Conventional Management Modalities}

Hyperbaric oxygen therapy and high-dose vitamins were once proposed for symptomatic CRN (50-52). Up to date, however, these approaches have barely shown any potency in reversing cerebral necrosis, and no cases of complete resolution on both symptom and MRI abnormality have ever been reported.

\section{NEW TREATMENT APPROACHES FOR CRN}

In recent years, with more understanding of the pathophysiology of CRN and the development of new drugs, some new management approaches using bevacizumab, nerve growth factor, gangliosides, and free radical scavengers have also found some striking results. A brief comparison of these agents is shown in Table 3 (55-59).

\section{Treatment With Bevacizumab}

Bevacizumab (Avastin), a humanized murine monoclonal antibody against the VEGF, has shown therapeutic effect in several solid tumors when used either alone or in combination with other cytotoxic drugs. Similar to tumor development in the vascular mechanism, $\mathrm{CRN}$ has been observed to response to
Bevacizumab as well. Gonzalez first demonstrated that bevacizumab alone or combinatively could improve CRNrelated edema with an underlying mechanism of normalizing the blood-brain barrier and reducing capillary leakage (55). As was widely accepted, VEGF overexpression is closely associated with radiation necrosis and subsequent brain edema (63), possibly by acting as a "vascular permeability factor" (64-66) that potently interrupts blood-brain barrier function and promotes vascular permeability. Therefore, blocking VEGF from approaching vascular targets could theoretically hinder fluid leak through capillary endothelium to the intercellular compartment, thus offering a plausible strategy for treating CRN.

Two retrospective studies have reported the experience of treating CRN with bevacizumab, one including six cases with histologically proven radionecrosis (67) and the other involving eight patients with MRI-based proof of CRN (55). Clinical stabilization or improvement and radiologic partial response and were observed in all cases. In a case report, a nearly complete response of the enhancement on MRI was observed after the use of bevacizumab (68), indicating that the process of CRN might be reversed. The first randomized placebocontrolled double-blind study that highlighted the role of bevacizumab in CRN was conducted in a small group of 14 patients by Levin et al. (69). After four doses of bevacizumab with 3-week interval, all patients in the treatment group showed improvement in neurologic symptoms or signs, compared to none in the control cases. Radiological evaluation on MRI scans showed that all patients treated with bevacizumab had a decrease in both the necrosis volume and the endothelial transfer constant. Tang et al. designed a larger-scaled randomized open-label study, in which 112 
NPC patients with radiation brain necrosis were randomly assigned to receive bevacizumab or corticosteroid (56). This trial demonstrated a remarkable superiority of bevacizumab in not only improving edema and enhancement on MRI, but also neurological symptoms and cognitive function. However, the 6-month recurrence rate of CRN was similar between two groups, suggesting that bevacizumab might have limited efficacy in maintaining long-term response. Moreover, it should be noticed that bevacizumab is associated with certain toxicities. In Levin's report, 6 of 11 patients receiving bevacizumab experienced adverse events, which included three serious cases with aspiration pneumonia, deep vein thrombosisinduced pulmonary embolism, and intracranial thrombosis. Tang reported an overall adverse events rate of $70.7 \%$, in which most frequently seen was hypertension.

\section{Treatment With Nerve Growth Factor}

Nerve growth factor (NGF) is one of the most prominent bioactive neurotrophic factors so far. NGF confers an important protective effect on central and peripheral nervous systems by preventing neural degeneration and promoting functional recovery of injured neurons (70). Given the evidence that radiation damage to oligodendrocytes and neurons is associated with late cerebral necrosis, we therefore postulated that NGF might be effective in treating cerebral radiation necrosis. The first case was treated with mouse NGF (mNGF) at $18 \mu \mathrm{g} /$ injection per day for 2 months. Three months later, a cognitive improvement was observed with an increase from 25 to 30 in Folstein and Folstein Mini-Mental State Examination score, which persisted till the time of last follow-up 9 months later (71). mNGF also achieve a surprisingly complete response on MRI in this patient, featured by the disappearance of the Swiss cheese-like presentations in bilateral temporal lobes. To our knowledge, this was the first report indicating a therapeutic potency of NGF in CRN. Following this case, a prospective phase II clinical trial was conducted to test the efficacy of mNGF for symptomatic TLN. Fourteen patients were enrolled in this study. All patients had radiologically proven TLN following definitive RT for nasopharyngeal carcinoma and progressive neurologic symptoms or signs. mNGF combined with pulsed corticosteroids were prescribed for 2 months. Eight months later, contrast-enhanced MRI scans showed that five and seven patients respectively had complete response and partial response in the necrotic volume, only two patients didn't respond to mNGF. Eight and five patients respectively showed complete and partial recovery in neurologic symptoms, while only one patient had no improvement. Adverse events were observed in three patients, all limited to mild injection site pain. This exploratory trial further demonstrated $\mathrm{mNGF}$ as a promising treatment option for TLN with minimal side effects (59).

\section{Treatment With Monosialotetrahexosylganglioside (GM1)}

Gangliosides exist with large concentration in the central nervous system (CNS). As acidic glycolipids that constitute the major component of cell membranes, gangliosides play an important role in several neuronal events, such as augmenting neurite outgrowth, inducing neuron regeneration, and restoring impaired neural function (72). Exogenous administration of monosialotetrahexosylganglioside (GM1), a ganglioside also known as Sygen, showed that GM1 had an obvious effect on the nervous system by accelerating functional recovery of cholinergic and dopaminergic activities after injury, and by protecting neurons against retrograde degeneration $(73,74)$, thus indicating its potential effect in treating CNS diseases. These encouraging results have facilitated clinical trials in stroke and spinal cord injury. A placebocontrolled, double-blind randomized trial in 37 patients with spinal cord injuries showed that GM1 led to a significant improvement in American Spinal Injury Association (ASIA) motor score within 1year follow-up (75). Another double-blind trial using GM1 in stroke also proved that gangliosides brought an improvement in neurologic scores that was more pronounced, more quickly and more persistent (76). Findings from another study show that GM1 ganglioside could powerfully ameliorate the cerebral edema in rats with mechanical lesion (77). Moreover, the function of GM1 in preventing retrograde degeneration and reducing the severity of behavioral effects after entorhinal lesions has also been reported (78). For CRN, in vivo experiments have also found a significant neuroprotective effect of GM1 on recovering learning and memory function in rats with radiation-induced brain injury (58). Although lack of clinical reports, GM1 has been applied in CRN across China for several years, with encouraging effect in ameliorating CRNrelated symptoms. The common prescription is intravenous use of GM1 at $60 \mathrm{mg}$ per day for 14 days, followed by $20 \mathrm{mg}$ per day for at least 14 days. A few necrotic masses have been shown to almost completely resolve on MRI scans 3 months after the application of GM1(unpublished data). However, despite single-institutional experience, detailed data regarding the specific effect of GM1 in CRN remain scarce, thus calling for large, placebo controlled randomized studies for further investigation.

\section{Treatment With Free Radical Scavengers}

As CRN is closely linked to intracranial oxidative stress, free radical scavengers such as Vitamin $\mathrm{E}$ and superoxide dismutase might theoretically benefit patients with $\mathrm{CRN}$ by eradicating oxygenderived free radicals. Edaravone, a novel free radical scavenger, has been demonstrated in vitro to protect neurogenesis after RT by restoring human neural stem cells' differentiation ability (79). In a prospective randomized clinical trial, edaravone provided significant improvement on MRI-detected edema as well as neurologic symptoms and signs (57). It would worth more trials to further elucidate the role of edaravone and other free radical scavengers in CRN.

\section{CONCLUSIONS}

With a declining incidence owing to new radiotherapy technologies, TLN remains a remarkable complication in locally advanced NPC patients. Dosimetric prevention is the most important approach to manage TLN. Based on the accumulating knowledge in dosevolume effect, it has been proposed that both unnecessary "hot spot" and excessive radiation volume in TLs should be avoided. As for existing TLN lesions, traditional treatment modalities like steroids, anti-coagulants, and surgery have been unsatisfactory in 
either efficacy or safety. In comparison, newly applied medications, including bevacizumab, GM1, and nerve growth factor, etc, have shown potency in mitigating TLN both radiologically and symptomatically, and even completely reversing TLN lesions without serious side effects. More clinical trials should be encouraged in future to better explore these agents.

\section{REFERENCES}

1. Sun Y, Zhou GQ, Qi ZY, Zhang L, Huang SM, Liu LZ, et al. Radiationinduced temporal lobe injury after intensity modulated radiotherapy in nasopharyngeal carcinoma patients: a dose-volume-outcome analysis. $B M C$ Cancer (2013) 13:397. doi: 10.1186/1471-2407-13-397

2. Tang Y, Luo D, Rong X, Shi X, Peng Y. Psychological disorders, cognitive dysfunction and quality of life in nasopharyngeal carcinoma patients with radiation-induced brain injury. PloS One (2012) 7:e36529. doi: 10.1371/ journal.pone. 0036529

3. Wang TM, Shen GP, Chen MY, Zhang JB, Sun Y, He J, et al. Genome-Wide Association Study of Susceptibility Loci for Radiation-Induced Brain Injury. J Natl Cancer Inst (2019) 111:620-8. doi: 10.1093/jnci/djy150

4. Zhou GQ, Yu XL, Chen M, Guo R, Lei Y, Sun Y, et al. Radiation-induced temporal lobe injury for nasopharyngeal carcinoma: a comparison of intensity-modulated radiotherapy and conventional two-dimensional radiotherapy. PloS One (2013) 8:e67488. doi: 10.1371/journal.pone. 0067488

5. Zeng L, Tian YM, Sun XM, Chen CY, Han F, Xiao WW, et al. Late toxicities after intensity-modulated radiotherapy for nasopharyngeal carcinoma: patient and treatment-related risk factors. Br J Cancer (2014) 110:49-54. doi: $10.1038 /$ bjc. 2013.720

6. Niu X, Hu C, Kong L. Experience with combination of cetuximab plus intensity-modulated radiotherapy with or without chemotherapy for locoregionally advanced nasopharyngeal carcinoma. J Cancer Res Clin Oncol (2013) 139:1063-71. doi: 10.1007/s00432-013-1419-Z

7. Ng WT, Ngan RKC, Kwong DLW, Tung SY, Yuen KT, Kam MK, et al. Prospective, Multicenter, Phase 2 Trial of Induction Chemotherapy Followed by Bio-Chemoradiotherapy for Locally Advanced Recurrent Nasopharyngeal Carcinoma. Int J Radiat Oncol Biol Phys (2018) 100:630-8. doi: 10.1016/ j.ijrobp.2017.11.038

8. Teo PM, Leung SF, Chan AT, Leung TW, Choi PH, Kwan WH, et al. Final report of a randomized trial on altered-fractionated radiotherapy in nasopharyngeal carcinoma prematurely terminated by significant increase in neurologic complications. Int J Radiat Oncol Biol Phys (2000) 48:1311-22. doi: 10.1016/S0360-3016(00)00786-0

9. Lee AW, Foo W, Chappell R, Fowler JF, Sze WM, Poon YF, et al. Effect of time, dose, and fractionation on temporal lobe necrosis following radiotherapy for nasopharyngeal carcinoma. Int J Radiat Oncol Biol Phys (1998) 40:35-42. doi: 10.1016/S0360-3016(97)00580-4

10. Peng G, Wang T, Yang KY, Zhang S, Zhang T, Li Q, et al. A prospective, randomized study comparing outcomes and toxicities of intensity-modulated radiotherapy vs. conventional two-dimensional radiotherapy for the treatment of nasopharyngeal carcinoma. Radiother Oncol (2012) 104:286-93. doi: 10.1016/ j.radonc.2012.08.013

11. Marks JE, Wong J. The risk of cerebral radionecrosis in relation to dose, time and fractionation. A follow-up study. Prog Exp Tumor Res (1985) 29:210-8. doi: $10.1159 / 000411642$

12. Lee AW, Ng SH, Ho JH, Poon YF, Au GK, Lau WH, et al. Clinical diagnosis of late temporal lobe necrosis following radiation therapy for nasopharyngeal carcinoma. Cancer (1988) 61:1535-42. doi: 10.1002/1097-0142(19880415) 61:8<1535::AID-CNCR2820610809>3.0.CO;2-E

13. Leung SF, Kreel L, Tsao SY. Asymptomatic temporal lobe injury after radiotherapy for nasopharyngeal carcinoma: incidence and determinants. $\mathrm{Br}$ J Radiol (1992) 65:710-4. doi: 10.1259/0007-1285-65-776-710

14. Mao YP, Zhou GQ, Liu LZ, Guo R, Sun Y, Li L, et al. Comparison of radiological and clinical features of temporal lobe necrosis in nasopharyngeal carcinoma patients treated with $2 \mathrm{D}$ radiotherapy or intensity-modulated radiotherapy. Br J Cancer (2014) 110:2633-9. doi: 10.1038/bjc.2014.243

\section{AUTHOR CONTRIBUTIONS}

$\mathrm{XZ}$ and $\mathrm{XW}$ contributed to the design of the review as well as the manuscript drafting and revision. PL organized the literature search and contributed to the manuscript revision. All authors contributed to the article and approved the submitted version.

15. Chau RM, Teo PM, Kam MK, Leung SF, Cheung KY, Chan AT. Dosimetric comparison between 2-dimensional radiation therapy and intensity modulated radiation therapy in treatment of advanced $\mathrm{T}$-stage nasopharyngeal carcinoma: to treat less or more in the planning organ-atrisk volume of the brainstem and spinal cord. Med Dosim (2007) 32:263-70. doi: 10.1016/j.meddos.2007.02.006

16. Ruben JD, Dally M, Bailey M, Smith R, McLean CA, Fedele P. Cerebral radiation necrosis: incidence, outcomes, and risk factors with emphasis on radiation parameters and chemotherapy. Int J Radiat Oncol Biol Phys (2006) 65:499-508. doi: 10.1016/j.jijrobp.2005.12.002

17. Lowenberg-Scharenberg K, Bassett RC. Amyloid degeneration of the human brain following X-ray therapy. J Neuropathol Exp Neurol (1950) 9:93-102, illust. doi: 10.1097/00005072-195001000-00006

18. Ali FS, Arevalo O, Zorofchian S, Patrizz A, Riascos R, Tandon N, et al. Cerebral Radiation Necrosis: Incidence, Pathogenesis, Diagnostic Challenges, and Future Opportunities. Curr Oncol Rep (2019) 21:66. doi: 10.1007/s11912019-0818-y

19. Furuse M, Nonoguchi N, Kawabata S, Miyatake SI, Kuroiwa T. Delayed brain radiation necrosis: pathological review and new molecular targets for treatment. Med Mol Morphol (2015) 48:183-90. doi: 10.1007/s00795-015$0123-2$

20. Belka C, Budach W, Kortmann RD, Bamberg M. Radiation induced CNS toxicity-molecular and cellular mechanisms. Br J Cancer (2001) 85:1233-9. doi: 10.1054/bjoc.2001.2100

21. Wong CS, Van der Kogel AJ. Mechanisms of radiation injury to the central nervous system: implications for neuroprotection. Mol Interv (2004) 4:27384. doi: $10.1124 / \mathrm{mi} .4 .5 .7$

22. Tofilon PJ, Fike JR. The radioresponse of the central nervous system: a dynamic process. Radiat Res (2000) 153:357-70. doi: 10.1667/0033-7587 (2000)153[0357:TROTCN]2.0.CO;2

23. Ljubimova NV, Levitman MK, Plotnikova ED, Eidus LK. Endothelial cell population dynamics in rat brain after local irradiation. $\mathrm{Br} J$ Radiol (1991) 64:934-40. doi: 10.1259/0007-1285-64-766-934

24. Pena LA, Fuks Z, Kolesnick RN. Radiation-induced apoptosis of endothelial cells in the murine central nervous system: protection by fibroblast growth factor and sphingomyelinase deficiency. Cancer Res (2000) 60:321-7.

25. Li YQ, Chen P, Haimovitz-Friedman A, Reilly RM, Wong CS. Endothelial apoptosis initiates acute blood-brain barrier disruption after ionizing radiation. Cancer Res (2003) 63:5950-6.

26. Lee N, Harris J, Garden AS, Straube W, Glisson B, Xia P, et al. Intensitymodulated radiation therapy with or without chemotherapy for nasopharyngeal carcinoma: radiation therapy oncology group phase II trial 0225. J Clin Oncol (2009) 27:3684-90. doi: 10.1200/JCO.2008.19.9109

27. Su SF, Huang Y, Xiao WW, Huang SM, Han F, Xie CM, et al. Clinical and dosimetric characteristics of temporal lobe injury following intensity modulated radiotherapy of nasopharyngeal carcinoma. Radiother Oncol (2012) 104:312-6. doi: 10.1016/j.radonc.2012.06.012

28. Zeng L, Huang SM, Tian YM, Sun XM, Han F, Lu TX, et al. Normal Tissue Complication Probability Model for Radiation-induced Temporal Lobe Injury after Intensity-modulated Radiation Therapy for Nasopharyngeal Carcinoma. Radiology (2015) 276:243-9. doi: 10.1148/radiol.14141721

29. Kong C, Zhu XZ, Lee TF, Feng PB, Xu JH, Qian PD, et al. LASSO-based NTCP model for radiation-induced temporal lobe injury developing after intensitymodulated radiotherapy of nasopharyngeal carcinoma. Sci Rep (2016) 6:26378. doi: 10.1038/srep26378

30. Wang J, Miao Y, Ou X, Wang X, He X, Shen C, et al. Development and validation of a model for temporal lobe necrosis for nasopharyngeal carcinoma patients with intensity modulated radiation therapy. Radiat Oncol (2019) 14:42. doi: 10.1186/s13014-019-1250-z 
31. Lee AW, Ng WT, Pan JJ, Chiang CL, Poh SS, Choi HC, et al. International Guideline on Dose Prioritization and Acceptance Criteria in Radiation Therapy Planning for Nasopharyngeal Carcinoma. Int J Radiat Oncol Biol Phys (2019) 105:567-80. doi: 10.1016/j.ijrobp.2019.09.030

32. Su SF, Huang SM, Han F, Huang Y, Chen CY, Xiao WW, et al. Analysis of dosimetric factors associated with temporal lobe necrosis (TLN) in patients with nasopharyngeal carcinoma (NPC) after intensity modulated radiotherapy. Radiat Oncol (2013) 8:17. doi: 10.1186/1748-717X-8-17

33. Zhou X, Ou X, Xu T, Wang X, Shen C, Ding J, et al. Effect of dosimetric factors on occurrence and volume of temporal lobe necrosis following intensity modulated radiation therapy for nasopharyngeal carcinoma: a case-control study. Int $J$ Radiat Oncol Biol Phys (2014) 90:261-9. doi: 10.1016/j.jrobp.2014.05.036

34. Feng M, Huang Y, Fan X, Xu P, Lang J, Wang D. Prognostic variables for temporal lobe injury after intensity modulated-radiotherapy of nasopharyngeal carcinoma. Cancer Med (2018) 7:557-64. doi: 10.1002/cam4.1291

35. Lu L, Sheng Y, Zhang G, Li Y, OuYang PY, Ge Y, et al. Temporal lobe injury patterns following intensity modulated radiotherapy in a large cohort of nasopharyngeal carcinoma patients. Oral Oncol (2018) 85:8-14. doi: 10.1016/ j.oraloncology.2018.07.020

36. Huang J, Kong FF, Oei RW, Zhai RP, Hu CS, Ying HM. Dosimetric predictors of temporal lobe injury after intensity-modulated radiotherapy for T4 nasopharyngeal carcinoma: a competing risk study. Radiat Oncol (2019) 14:31. doi: 10.1186/s13014-019-1229-9

37. Gou X, Duan B, Shi H, Qin L, Xiao J, Chen N. The relations of dosimetric parameters with long-term outcomes and late toxicities in advanced T-stage nasopharyngeal carcinoma with IMRT. Head Neck (2020) 42:85-92. doi: 10.1002/hed.25986

38. van der Maazen RW, Kleiboer BJ, Verhagen I, Van Der Kogel AJ. Irradiation in vitro discriminates between different $\mathrm{O}-2 \mathrm{~A}$ progenitor cell subpopulations in the perinatal central nervous system of rats. Radiat Res (1991) 128:64-72. doi: $10.2307 / 3578068$

39. van der Maazen RW, Kleiboer BJ, Verhagen I, Van Der Kogel AJ. Repair capacity of adult rat glial progenitor cells determined by an in vitro clonogenic assay after in vitro or in vivo fractionated irradiation. Int J Radiat Biol (1993) 63:661-6. doi: 10.1080/09553009314450861

40. van der Maazen RW, Verhagen I, Kleiboer BJ, Van Der Kogel AJ. Radiosensitivity of glial progenitor cells of the perinatal and adult rat optic nerve studied by an in vitro clonogenic assay. Radiother Oncol (1991) 20:25864. doi: 10.1016/0167-8140(91)90125-Z

41. Castel JC, Caille JM. Imaging of irradiated brain tumours. Value of magnetic resonance imaging. J Neuroradiol (1989) 16:81-132.

42. Sundgren PC, Cao Y. Brain irradiation: effects on normal brain parenchyma and radiation injury. Neuroimaging Clin N Am (2009) 19:657-68. doi: 10.1016/j.nic.2009.08.014

43. Groves AK, Barnett SC, Franklin RJ, Crang AJ, Mayer M, Blakemore WF, et al. Repair of demyelinated lesions by transplantation of purified O-2A progenitor cells. Nature (1993) 362:453-5. doi: 10.1038/362453a0

44. Brustle O, Jones KN, Learish RD, Karram K, Choudhary K, Wiestler OD, et al. Embryonic stem cell-derived glial precursors: a source of myelinating transplants. Science (1999) 285:754-6. doi: 10.1126/science.285.5428.754

45. Ijichi A, Noel F, Sakuma S, Weil MM, Tofilon PJ. Ex vivo gene delivery of platelet-derived growth factor increases $0-2 \mathrm{~A}$ progenitors in adult rat spinal cord. Gene Ther (1996) 3:389-95.

46. Sheline GE, Wara WM, Smith V. Therapeutic irradiation and brain injury. Int $J$ Radiat Oncol Biol Phys (1980) 6:1215-28. doi: 10.1016/0360-3016(80)90175-3

47. Lam TC, Wong FC, Leung TW, Ng SH, Tung SY. Clinical outcomes of 174 nasopharyngeal carcinoma patients with radiation-induced temporal lobe necrosis. Int J Radiat Oncol Biol Phys (2012) 82:e57-65. doi: 10.1016/j.ijrobp.2010.11.070

48. Happold C, Ernemann U, Roth P, Wick W, Weller M, Schmidt F. Anticoagulation for radiation-induced neurotoxicity revisited. J Neurooncol (2008) 90:357-62. doi: 10.1007/s11060-008-9674-6

49. Glantz MJ, Burger PC, Friedman AH, Radtke RA, Massey EW, Schold SC. Treatment of radiation-induced nervous system injury with heparin and warfarin. Neurology (1994) 44:2020-7. doi: 10.1212/WNL.44.11.2020

50. Co J, De Moraes MV, Katznelson R, Evans AW, Shultz D, Laperriere N, et al. Hyperbaric Oxygen for Radiation Necrosis of the Brain. Can J Neurol Sci (2019) 2019:1-8. doi: 10.1017/cjn.2019.290
51. Chuba PJ, Aronin P, Bhambhani K, Eichenhorn M, Zamarano L, Cianci P, et al. Hyperbaric oxygen therapy for radiation-induced brain injury in children. Cancer (1997) 80:2005-12. doi: 10.1002/(SICI)1097-0142 (19971115)80:10<2005::AID-CNCR19>3.0.CO;2-0

52. Valadao J, Pearl J, Verma S, Helms A, Whelan H. Hyperbaric oxygen treatment for post-radiation central nervous system injury: a retrospective case series. Undersea Hyperb Med (2014) 41:87-96.

53. Fang W, Gu B, Jing X, Xiao S, Fan S, Liao W, et al. Late-onset cystic brain necrosis after radiotherapy for nasopharyngeal carcinoma. Jpn J Clin Oncol (2017) 47:499-504. doi: 10.1093/jjco/hyx028

54. Mou YG, Sai K, Wang ZN, Zhang XH, Lu YC, Wei DN, et al. Surgical management of radiation-induced temporal lobe necrosis in patients with nasopharyngeal carcinoma: report of 14 cases. Head Neck (2011) 33:1493500. doi: 10.1002/hed.21639

55. Gonzalez J, Kumar AJ, Conrad CA, Levin VA. Effect of bevacizumab on radiation necrosis of the brain. Int J Radiat Oncol Biol Phys (2007) 67:323-6. doi: 10.1016/j.ijrobp.2006.10.010

56. Xu Y, Rong X, Hu W, Huang X, Li Y, Zheng D, et al. Bevacizumab Monotherapy Reduces Radiation-induced Brain Necrosis in Nasopharyngeal Carcinoma Patients: A Randomized Controlled Trial. Int J Radiat Oncol Biol Phys (2018) 101:1087-95. doi: 10.1016/j.jirobp.2018.04.068

57. Tang Y, Rong X, Hu W, Li G, Yang X, Yang J, et al. Effect of edaravone on radiation-induced brain necrosis in patients with nasopharyngeal carcinoma after radiotherapy: a randomized controlled trial. J Neurooncol (2014) 120:441-7. doi: 10.1007/s11060-014-1573-4

58. Tang YM, Xing YG, LI M, Shen J, Xiao SH, LI XP. Neuroprotective effect of GM1 ganglioside on learning and memory impairment in rats with brain radiation. Chin J Clin Pharmacol Ther (2003) 8:518-21.

59. Wang XS, Ying HM, He XY, Zhou ZR, Wu YR, Hu CS. Treatment of cerebral radiation necrosis with nerve growth factor: A prospective, randomized, controlled phase II study. Radiother Oncol (2016) 120:69-75. doi: 10.1016/ j.radonc.2016.04.027

60. Zhuo X, Huang X, Yan M, Li H, Li Y, Rong X, et al. Comparison between high-dose and low-dose intravenous methylprednisolone therapy in patients with brain necrosis after radiotherapy for nasopharyngeal carcinoma. Radiother Oncol (2019) 137:16-23. doi: 10.1016/j.radonc.2019.04.015

61. Woo E, Lam K, Yu YL, Lee PW, Huang CY. Cerebral radionecrosis: is surgery necessary? J Neurol Neurosurg Psychiatry (1987) 50:1407-14. doi: 10.1136/ jnnp.50.11.1407

62. Shaw PJ, Bates D. Conservative treatment of delayed cerebral radiation necrosis. J Neurol Neurosurg Psychiatry (1984) 47:1338-41. doi: 10.1136/jnnp.47.12.1338

63. Kim JH, Chung YG, Kim CY, Kim HK, Lee HK. Upregulation of VEGF and FGF2 in normal rat brain after experimental intraoperative radiation therapy. J Korean Med Sci (2004) 19:879-86. doi: 10.3346/jkms.2004.19.6.879

64. Dvorak HF, Sioussat TM, Brown LF, Berse B, Nagy JA, Sotrel A, et al. Distribution of vascular permeability factor (vascular endothelial growth factor) in tumors: concentration in tumor blood vessels. J Exp Med (1991) 174:1275-8. doi: 10.1084/ jem.174.5.1275

65. Senger DR, Perruzzi CA, Feder J, Dvorak HF. A highly conserved vascular permeability factor secreted by a variety of human and rodent tumor cell lines. Cancer Res (1986) 46:5629-32.

66. Senger DR, Van de Water L, Brown LF, Nagy JA, Yeo KT, Yeo TK, et al. Vascular permeability factor (VPF, VEGF) in tumor biology. Cancer Metastasis Rev (1993) 12:303-24. doi: 10.1007/BF00665960

67. Torcuator R, Zuniga R, Mohan YS, Rock J, Doyle T, Anderson J, et al. Initial experience with bevacizumab treatment for biopsy confirmed cerebral radiation necrosis. J Neurooncol (2009) 94:63-8. doi: 10.1007/s11060-0099801-z

68. Wong ET, Huberman M, Lu XQ, Mahadevan A. Bevacizumab reverses cerebral radiation necrosis. J Clin Oncol (2008) 26:5649-50. doi: 10.1200/JCO.2008.19.1866

69. Levin VA, Bidaut L, Hou P, Kumar AJ, Wefel JS, Bekele BN, et al. Randomized double-blind placebo-controlled trial of bevacizumab therapy for radiation necrosis of the central nervous system. Int J Radiat Oncol Biol Phys (2011) 79:1487-95. doi: 10.1016/j.ijrobp.2009.12.061

70. Luk YO, Chen WY, Wong WJ, Hu HH, Hsu LC, Chern CM, et al. Treatment of focal cerebral ischemia with liposomal nerve growth factor. Drug Deliv (2004) 11:319-24. doi: 10.1080/10717540490494104 
71. Wang X, Ying H, Zhou Z, Hu C, Eisbruch A. Successful treatment of radiation-induced temporal lobe necrosis with mouse nerve growth factor. J Clin Oncol (2011) 29:e166-168. doi: 10.1200/JCO.2010.31.7081

72. Ferrari G, Fabris M, Gorio A. Gangliosides enhance neurite outgrowth in PC12 cells. Brain Res (1983) 284:215-21. doi: 10.1016/0165-3806(83) 90006-8

73. Toffano G, Savoini GE, Moroni F, Lombardi G, Calzà L, Agnati LF. Chronic GM1 ganglioside treatment reduces dopamine cell body degeneration in the substantia nigra after unilateral hemitransection in rat. Brain Res (1984) 296:233-9. doi: 10.1016/0006-8993(84)90061-1

74. Wojcik M, Ulas J, Oderfeld-Nowak B. The stimulating effect of ganglioside injections on the recovery of choline acetyltransferase and acetylcholinesterase activities in the hippocampus of the rat after septal lesions. Neuroscience (1982) 7:495-9. doi: 10.1016/0306-4522(82)90282-2

75. Geisler FH, Dorsey FC, Coleman WP. Recovery of motor function after spinalcord injury-a randomized, placebo-controlled trial with GM-1 ganglioside. N Engl J Med (1991) 324:1829-38. doi: 10.1056/NEJM199106273242601

76. Bassi S, Albizzati MG, Sbacchi M, Frattola L, Massarotti M. Double-blind evaluation of monosialoganglioside (GM1) therapy in stroke. J Neurosci Res (1984) 12:493-8. doi: 10.1002/jnr.490120232
77. Karpiak SE, Mahadik SP. Reduction of cerebral edema with GM1 ganglioside. J Neurosci Res (1984) 12:485-92. doi: 10.1002/jnr.490120231

78. Fass B, Ramirez JJ. Effects of ganglioside treatments on lesion-induced behavioral impairments and sprouting in the CNS. J Neurosci Res (1984) 12:445-58. doi: 10.1002/jnr.490120228

79. Ishii J, Natsume A, Wakabayashi T, Takeuchi H, Hasegawa H, Kim SU, et al. The free-radical scavenger edaravone restores the differentiation of human neural precursor cells after radiation-induced oxidative stress. Neurosci Lett (2007) 423:225-30. doi: 10.1016/j.neulet.2007.07.029

Conflict of Interest: The authors declare that the research was conducted in the absence of any commercial or financial relationships that could be construed as a potential conflict of interest.

Copyright $\odot 2021$ Zhou, Liu and Wang. This is an open-access article distributed under the terms of the Creative Commons Attribution License (CC BY). The use, distribution or reproduction in other forums is permitted, provided the original author $(s)$ and the copyright owner(s) are credited and that the original publication in this journal is cited, in accordance with accepted academic practice. No use, distribution or reproduction is permitted which does not comply with these terms. 